\title{
Model Compounds of Humic Acid and Oxovanadium Cations. Potentiometric Titration and EPR Spectroscopy Studies
}

\author{
Ana Lucia Ramalho Mercêै*, Ivana Helena Zamuner Spir, Maria José \\ Oruña Salmón", Ricardo Alberto Giannoni, and Antonio Sálvio Mangrich
}

Departamento de Química, Universidade Federal do Paraná, C.P. 19081,

\author{
81531-990 Curitiba - PR, Brazil
}

\begin{abstract}
As constantes de estabilidade e parâmetros isotrópicos de EPR ( $\mathrm{A}_{\mathrm{o}}$ e $\left.\mathrm{g}_{\mathrm{o}}\right)$ foram obtidos por titulações potenciométricas e espectroscopia de EPR, empregando-se soluções aquosas, $15 \% \mathrm{v} / \mathrm{v}$ etanol, de compostos modelo de ácido húmico - ácido salicílico (SALA) - e do artefato de laboratório, ácido nitrohúmico - ácidos 3-nitrossalicílico (3-NSA), 5-nitrossalicílico (5-NSA) e 3,5-dinitrossalicílico - e cátions oxovanádio.

Espectros de EPR foram obtidos de soluções dos compostos modelo e o íon $\mathrm{VO}^{2+}$ (V(IV), e as constantes de estabilidade foram obtidas com solução de $\mathrm{VO}^{3+}(\mathrm{V}(\mathrm{V})$, sendo que os valores obtidos são $12.77 \pm 0.04$ até $7.06 \pm 0.05$ para as espécies ML, e $9.90 \pm 0.04$ até $4.06 \pm 0.05$ para as espécies ML2, de acordo com a diminuição na acidez dos grupos carboxílico e fenólico com a introdução dos substituintes nitro- no anel aromático dos compostos modelo estudados.

Os parâmetros de EPR demonstraram que os valores de $g_{0}$ aumentam e os valores de $A_{o}$ diminuem concomitante ao aumento dos logaritmos das constantes de formação globais encontrados para os complexos.
\end{abstract}

The stability constants and the isotropic EPR parameters $A_{o}$ (hyperfine splitting constant) and $\mathrm{g}_{\mathrm{o}}$ ( $\mathrm{g}$ value) were obtained by potentiometric titrations and EPR spectroscopy, respectively, of $85 \% \mathrm{v} / \mathrm{v}$ aqueous solutions of model compounds of humic acids - salicylic acid (SALA) - and both nitrohumic acids, a laboratory artifact - nitrosalicylic acids, 3-nitrosalicylic acid (3-NSA), 5-nitrosalicylic acid (5-NSA) and 3,5-dinitrosalicylic acid (3,5-DNSA) and oxovanadium cations.

It was possible to record EPR spectra of those model compounds and the ion $\mathrm{VO}^{2+}(\mathrm{V}(\mathrm{IV}))$, and the stability constants were obtained from a solution of $\mathrm{VO}^{3+}(\mathrm{V}(\mathrm{V}))$, the values for the logarithms of the stability constants ranging from $12.77 \pm 0.04$ to $7.06 \pm 0.05$ for the species ML, and from $9.90 \pm 0.04$ to $4.06 \pm 0.05$ for the species $\mathrm{ML}_{2}$ according to the decrease in the acidity of the carboxylic and the hydroxyl groups in the aromatic ring of the model compounds studied as the $-\mathrm{NO}_{2}$ substituents were added. Species distribution diagrams were also obtained for the equilibria studied.

The EPR parameters showed that as the logarithm of the overall stability constants increase, $\mathrm{g}_{\mathrm{o}}$ values also increase, while $A_{o}$ values show a tendency to decrease.

Keywords: humic acid, model compounds, equilibrium constants, oxovanadium cations

\section{Introduction}

The importance of vanadium in biological systems ${ }^{1}$ is imparted mainly by the rich oxygen chemistry, being $\mathrm{VO}^{2+}$ and $\mathrm{VO}_{2}{ }^{+}$examples of oxocations being associated as important catalysts exerting defense and protection functions and being also a cofactor of nitrogenase in the fixation of dinitrogen. As a micronutrient in living organisms, vanadium is important to prevent growth retardation and skeletal deformations in animals, and possibly participates in regulation of enzymatic processes. Further some complexes of $\mathrm{V}(\mathrm{IV})$ and $\mathrm{V}(\mathrm{V})$ have shown insulin-mimetic actions ${ }^{2-4}$.

Humic acids present heterogeneous compositions that depend on the chemistry of how they were generated. Thus to unambiguously identify their structures is a difficult task. However it is known ${ }^{5}$ that within these geopolymers the main chelating groups are catechol, salicylate and phthalate

e-mail: anamerce@quimica.ufpr.br

\# summer student from Cantabria - Spain 
derivatives which are distributed throught the humic acid structure.

The cation exchange capacity - CEC - which regulates the availability of metal ions in the soil, is dependent upon variations of $\mathrm{pH}$ values. These cation exchange reactions involve the labile protons on soil humus and are directly related to the functional groups present, such as carboxyl, carbonyl, amino, imidazole, phenolic and alcoholic hydroxyl and sulfhydryl groups ${ }^{6}$ as represented generally in Eq. 1:

$$
\mathrm{SH}_{2(\mathrm{~s})}+\mathrm{M}_{(\mathrm{aq})}^{2+} \rightleftharpoons \mathrm{SM}_{(\mathrm{s})}+2 \mathrm{H}^{+}
$$

Studies involving VO(IV) and coal nitrohumic acid ${ }^{7}$ showed how this cation is important as a probe in EPR studies as well as unravelled the sites of complexation, which turned out to be through o-hydroxycarboxylic aromatic (salicylic) basic sites as equatorial ligands of $\mathrm{VO}^{2+}$ oxocation. A study ${ }^{8}$ of the EPR parameters in natural and synthetic complexes of vanadyl ion - humic acids also revealed participation of the salycilate basic sites in the complex. Further reported studies employing potentiometric, spectrophotometric titrations ${ }^{9-10}$ and EPR Spectroscopy $^{9-11}$ have investigated the complex formation of deferoxamine $\mathrm{B}$ and $\mathrm{VO}^{2+}$ and $\mathrm{VO}_{2}{ }^{+}$oxocations ${ }^{9}$, the complex formation of $\mathrm{VO}^{2+}$ and citric and tartaric acids ${ }^{10}$ and the biosorption of $\mathrm{VO}^{2+}$ by the roots of some plants ${ }^{11}$.

The present study involved potentiometric titration and EPR techniques in order to measure the interaction between salicylic basic sites present in humic acid and nitrosalicylic basic sites present in nitrohumic acids, the latter, a laboratory artifact $^{7}$, and oxovanadium cations by determining their stability constants. The obtained EPR parameters were compared with the stability constants in order to determine if there was a correlation.

The model compounds chosen are salicylic acid for humic acids and nitrosalicylic acids for nitrohumic acids (for the structures refer to Ref. 12).

\section{Materials and Methods}

All chemicals were used without further purification. $\mathrm{KCl}$ (J.T.Baker - USA) was the supporting electrolyte. Aqueous 85\%v/v:15\%v/v ethanolic (Merck - Brasil) solutions $\left(0.1 \mathrm{~mol} \mathrm{~L}^{-1}\right)$ of the ligands salicylic acid (SALA Reagen - Brasil), 3-nitrosalicylic acid (3-NSA), 5-nitrosalicylic acid (5-NSA) and 3,5-dinitrosalicylic acid (3,5DNSA), TCI - Japan, and $0.1 \mathrm{~mol} \mathrm{~L}^{-1} \mathrm{KOH}$ (Merck - Brasil) were prepared in double distilled and deionized carbonate - free water. The $\mathrm{KOH}$ solutions were standardized against potassium acid phthalate. The vanadyl solutions were prepared in two different ways as follows. In the first one, a proper mass of the $\mathrm{VOSO}_{4} \cdot \mathrm{nH}_{2} \mathrm{O}\left(0.1 \mathrm{~mol} \mathrm{~L}^{-1}\right.$ - Aldrich USA) was dissolved in an aqueous $0.36 \mathrm{~mol} \mathrm{~L}^{-1} \mathrm{H}_{2} \mathrm{SO}_{4}$ (Reagen - Brasil) solution $\left(\mathrm{VO}^{2+}\right)$. In the second one a mass of $\mathrm{VOSO}_{4} \cdot \mathrm{nH}_{2} \mathrm{O}\left(0.1 \mathrm{~mol} \mathrm{~L}^{-1}\right.$ - Aldrich - USA) was dis- solved in an aqueous $0.4 \mathrm{~mol} \mathrm{~L}{ }^{-1} \mathrm{HNO}_{3}$ (Merck - Brasil) solution $\left(\mathrm{VO}^{3+}\right)$. The $\mathrm{H}^{+}$content was measured by Gran's $\mathrm{Plot}^{13}$ and the vanadyl ion by titration with $\mathrm{KMnO}_{4}{ }^{14}$.

\section{Potentiometric equilibrium measurements}

Following the procedures described in the literature $^{12,13-15}$ all the possible errors arising in calculating unknown equilibrium constants by least-square techniques were minimized. Three titrations were performed with the metal ion and each ligand. All the potentiometric studies were carried out in a Micronal (Brasil) model B-375 research pHmeter fitted with blue glass and calomel reference electrodes calibrated with standard $\mathrm{HCl} 10^{-2} \mathrm{~mol} \mathrm{~L}^{-1}(\mu=$ $\left.0.100 \mathrm{~mol} \mathrm{~L}^{-1}(\mathrm{KCl})\right)$ and $\mathrm{KOH}$ aqueous $85 \% \mathrm{v} / \mathrm{v}$ : $15 \% \mathrm{v} / \mathrm{v}$ ethanolic solutions to read $-\log \left[\mathrm{H}^{+}\right](\mathrm{p}[\mathrm{H}])$ directly, under a stream of purified $\mathrm{N}_{2}$ (White-Martins - Brasil). The temperature was maintained at $25.0 \pm 0.1{ }^{\circ} \mathrm{C}$ and the ionic strenght adjusted to $0.100 \mathrm{~mol} \mathrm{~L}^{-1}$ by the proper addition of $\mathrm{KCl}$.

All solutions were titrated with $0.1 \mathrm{~mol} \mathrm{~L}^{-1}$ standard $\mathrm{CO}_{2}$-free $\mathrm{KOH}$ solutions in duplicate. The $\mathrm{p}[\mathrm{H}]$ range was from 2.0 to 11.0. In the callibration step of the pHmeter the $\mathrm{p}[\mathrm{H}]$ reproducibility is $<0.005$ units of $\mathrm{p}[\mathrm{H}]$ at acidi region and $<0.015$ at basic $\mathrm{p}[\mathrm{H}]$ region.

\section{Computations}

The protonation constants of the ligands employed were reported earlier ${ }^{12}$ according to Eqs. 2 and 3. The hydrolysis constants of vanadyl ion were taken from the literature ${ }^{16}$. The species considered in the calculations were M:L (being $\mathrm{M}=\mathrm{VO}^{2+}$ or $\mathrm{VO}^{3+}$ and $\mathrm{L}=$ sacilicylate derivatives) $1: 1$, $1: 2 ; 2: 1 ; 2: 2$ and their protonated ones.

$$
\begin{array}{ll}
\mathrm{L}+\mathrm{H} \rightleftharpoons \mathrm{HL} & \log \mathrm{K}_{1}=\frac{[\mathrm{HL}]}{[\mathrm{L}] \cdot[\mathrm{H}]} \\
\mathrm{HL}+\mathrm{H} \rightleftharpoons \mathrm{H}_{2} \mathrm{~L} & \log \mathrm{K}_{2}=\frac{\left[\mathrm{H}_{2} \mathrm{~L}\right]}{[\mathrm{HL}] \cdot[\mathrm{H}]}
\end{array}
$$

Thecalculationsemployedthemicrocomputerprogram Best $7^{13}$ and the species distribution diagrams were calculated with the microcomputer program $\mathrm{SPE}^{13}$. The Best7 program calculation begins with the set of known and unknown (estimated) overall stability constants (Eq. 4) and computes $\left[\mathrm{H}^{+}\right]$at the equilibrium for each quantity of added base. For each equilibrium point, the fitting process consists in the minimization of the differences between the observed and the calculated $\mathrm{p}[\mathrm{H}]$ values by using a weighted least square method. The iterative process is repeated until no further minimization is obtained. All other mathematical aspects are described elsewhere ${ }^{12-13,15}$.

$$
\mathrm{M}+\mathrm{nL} \rightleftharpoons \mathrm{ML}_{\mathrm{n}} \quad \log \beta_{\mathrm{n}}=\frac{\left[\mathrm{ML}_{\mathrm{n}}\right]}{[\mathrm{M}] \cdot[\mathrm{L}]^{\mathrm{n}}}
$$




\section{EPR spectra}

A Bruker ESP 300E spectrometer was used to acquire the spectra of the oxovanadium complexes in aqueous solutions in the ratio metal to ligand $1: 1$ to the nitrosalicylic acids and in the ratio $1: 1$ and 1:2 (M:L) for salicylic acid and $\mathrm{VO}^{2+}$ at room temperature $(300 \mathrm{~K})$ in thin quartz tubes operating at a frequency of $\cong 9.5 \mathrm{GHz}$ (X-band) with a $100 \mathrm{KHz}$ modulation frequency. The $\mathrm{p}[\mathrm{H}]$ of the solutions was controlled with aqueous solution of $\mathrm{KOH}(0.001 \mathrm{~mol}$ $\mathrm{L}^{-1}$ ) trying to sample the maximum possible concentration of each formed species according to the distribution diagrams for each studied solution (refer to Figs. 5 to 8).

\section{Results and Discussion}

The first attempt to measure overall stability constants using potentiometric titrations was made with $\mathrm{VOSO}_{4}$ in $\mathrm{H}_{2} \mathrm{SO}_{4}$ solution. The results have shown that due to the competition of the $\mathrm{SO}_{4}{ }^{2-}$ ion in the equilibrium, only the first complexed species (ML) could be detected, before the whole system precipitated. These solutions however were investigated by EPR spectrometer in order to measure the $\mathrm{A}_{\mathrm{o}}$ and $\mathrm{g}_{\mathrm{o}}$ parameters. The results are presented in Table 1.

In order to delay the precipitation of this system, a solution of $\mathrm{VOSO}_{4}$ in $\mathrm{HNO}_{3}$ was investigated. However, in the presence of this acid, V(IV) would invariably be oxidised to $\mathrm{V}(\mathrm{V})$, an EPR silent valence. For the potentiometric titrations it turned out to be very useful, rendering not only values for the stability constants of ML, which were in perfect agreement with those obtained with the $\mathrm{H}_{2} \mathrm{SO}_{4}$ solution, but also values for MHL for some ligands, and $\mathrm{ML}_{2}$ for all four ligands studied (Table 2).

Table 1. EPR isotropic parameters for oxovanadium (IV) salicylate derivative complexes in aqueous solutions.

\begin{tabular}{lcccc}
\hline Ligand & $\mathrm{M}: \mathrm{L}$ & $\mathrm{g}_{\mathrm{o}}$ & $\mathrm{A}_{\mathrm{o}}$ (Gauss) & $\log \beta$ \\
\hline 3, 5-DNSA & $1: 1$ & 1.9636 & 108 & 7.06 \\
5-NSA & $1: 1$ & 1.9654 & 108 & 9.00 \\
3-NSA & $1: 1$ & 1.9666 & 108 & 9.68 \\
SALA & $1: 1$ & 1.9685 & 107 & 12.77 \\
SALA & $1: 2$ & 1.9696 & 100 & 22.67 \\
\hline
\end{tabular}

The potentiometric equilibrium curves are depicted in Figures 1 for 4 of 0.1 mmole of SALA, 3-NSA, 5-NSA and 3,5-DNSA with 0.1 and 0.05 mmole of $\mathrm{VO}^{3+}$, respectively.

In Fig. 1, both ratios present buffers until approximately $\mathrm{p}[\mathrm{H}]$ 6.0, after which the formation of insoluble products prevented further acquisition of data. In Fig. 2 the buffer for the ratio $1: 1$ approached $\mathrm{p}[\mathrm{H}] 4.9$ and for the ratio $\mathrm{M}: \mathrm{L}$ of $1: 2$, approached $\mathrm{p}[\mathrm{H}] 3.1$ with an inflection until $\mathrm{p}[\mathrm{H}]$ 5.5 , after which formation of insoluble products occurred. In Fig. 3 the buffering action was observed for the ratio 1:1 until precipitation began to occur at approximately $\mathrm{p}[\mathrm{H}]$ 5.0. The ratio 1:2, besides acting as a buffer until approximately $\mathrm{p}[\mathrm{H}] 4.0$, presents an infection until near $\mathrm{p}[\mathrm{H}] 8.2$ after which further titration was prevented due to precipitation of products. Fig, 4 reveals the presence of a buffer for the ratio $1: 1$ until near $\mathrm{p}[\mathrm{H}] 4.3$ and the $1: 2$ ratio acts as a buffer until approximately $\mathrm{p}[\mathrm{H}] 3.8$ thereafter an inflection being observed until $\mathrm{p}[\mathrm{H}] 6.2$ after which precipitation occurred.

The calculated stability constants provided the diagrams for the species distribution (Figs. 5 to 8 for $2.5 \times 10^{-3}$ mol L ${ }^{-1}$ of SALA and $1.25 \times 10^{-3} \mathrm{~mol} \mathrm{~L}^{-1}$ for $\mathrm{VO}^{3+}, 3-\mathrm{NSA}$ - $\mathrm{VO}^{3+}, 5-\mathrm{NSA}-\mathrm{VO}^{3+}$, and 3,5-DNSA - $\mathrm{VO}^{3+}$, respectively). The formation of $\mathrm{ML}$ starts at $\mathrm{p}[\mathrm{H}] \cong 3.0$ reaching its maximum formation near $\mathrm{p}[\mathrm{H}] 5.3$, disappearing at $\mathrm{p}[\mathrm{H}] \cong 9.0$; and $\mathrm{ML}_{2}$ starts at $\mathrm{p}[\mathrm{H}] \cong 6.0$ reaching its maximum at $\mathrm{p}[\mathrm{H}] \cong 10.0$. For $3-\mathrm{NSA}^{-} \mathrm{VO}^{3+}$ (Fig. 6) $\mathrm{ML}$ starts at $\mathrm{p}[\mathrm{H}] \cong 2.8$, reaching its maximum at $\mathrm{p}[\mathrm{H}] 4.8$, disappearing at $\mathrm{p}[\mathrm{H}] \cong 9.0 ; \mathrm{ML}_{2}$ starts at $\mathrm{p}[\mathrm{H}] \cong 5.0$, reaching its maximum at 9.9. In Fig. 7 the formation of ML starts and ends around $\mathrm{p}[\mathrm{H}]$ values of 3.0 and 9.0 respectively, reaching a maximum at $\mathrm{p}[\mathrm{H}] \cong 5.5$; and $\mathrm{ML}_{2}$ starts at 6.5 and reaching its maximum at 10.4. Fig. 8 shows the formation of $\mathrm{ML}$ starting and ending at $\mathrm{p}[\mathrm{H}] \cong 3.0$ and 9.0 respectively, reaching its maximum at 4.8. MHL is at its maximum at $\mathrm{p}[\mathrm{H}] 2.0$, disappearing around $\mathrm{p}[\mathrm{H}]$ 4.0. $\mathrm{ML}_{2}$ starts at $\mathrm{p}[\mathrm{H}] \cong 5.0$, reaches its maximum at 8.2 , disappearing after $\mathrm{p}[\mathrm{H}] 10.0$.

A closer look at the region of $\mathrm{p}[\mathrm{H}]$ near 7.0 , which besides being the phisiological $\mathrm{p}[\mathrm{H}]$ is also the required value for a healthy soil and natural waters, the complexes species observed in this work $\left(\mathrm{ML}\right.$ and $\left.\mathrm{ML}_{2}\right)$ are present in

Table 2. Logarithms of the equilibrium constants of salicylate derivatives and $\mathrm{VO}^{3+}$ complexes $\left(\mathrm{T}=25^{\circ} \mathrm{C} ; \mu=0.100 \mathrm{~mol} \mathrm{~L}^{-1}(\mathrm{KCl})\right)$.

\begin{tabular}{lcccc}
\hline $\log \mathrm{K}$ & $\mathrm{SALA} \mathrm{VO}^{3+}$ & $3-\mathrm{NSA}^{\mathrm{V}} \mathrm{VO}^{3+}$ & $5-\mathrm{NSA}^{\mathrm{V}} \mathrm{VO}^{3+}$ & $3,5-\mathrm{DNSA}^{\mathrm{V}} \mathrm{VO}^{3+}$ \\
\hline$[\mathrm{ML}] /[\mathrm{M}][\mathrm{L}]$ & $12.77^{\mathrm{a}}$ & $9.68^{\mathrm{b}}$ & $9.00^{\mathrm{a}}$ & $7.06^{\mathrm{c}}$ \\
{$[\mathrm{MHL}] /[\mathrm{ML}][\mathrm{H}]$} & n.d. & $3.37^{\mathrm{b}}$ & n.d. & $3.37^{\mathrm{c}}$ \\
{$\left[\mathrm{ML}_{2}\right] /[\mathrm{ML}][\mathrm{L}]$} & $9.90^{\mathrm{a}}$ & $5.02^{\mathrm{b}}$ & $5.64^{\mathrm{a}}$ & $4.06^{\mathrm{c}}$ \\
\hline
\end{tabular}

\footnotetext{
$\mathrm{a}_{\text {standard deviation }}=0.04$.

$\mathrm{b}_{\text {standard deviation }}=0.06$.

$\mathrm{c}_{\text {standard deviation }}=0.05$.

n.d $=$ not detected.
} 


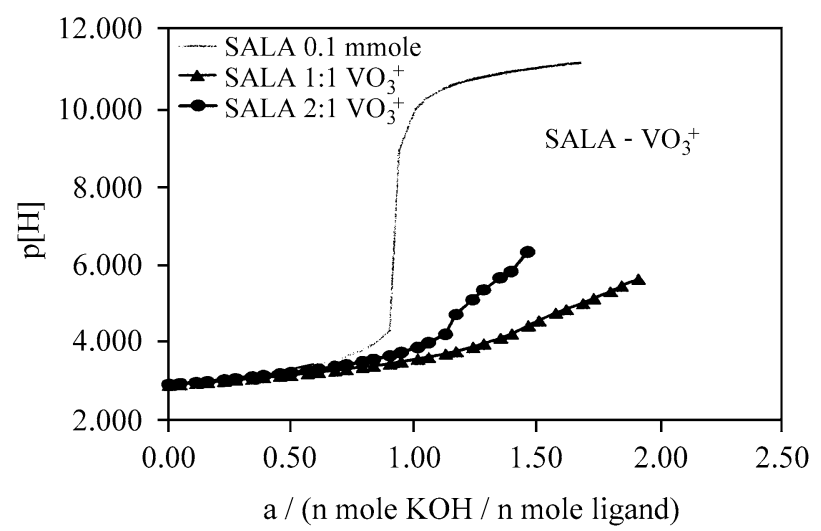

Figure 1. Potentiometric $\mathrm{p}[\mathrm{H}]$ profiles of $40 \mathrm{~mL}$ of SALA $\left(0.01 \mathrm{~mol} \mathrm{~L}^{-1}\right.$; $\mu=0.100 \mathrm{~mol} \mathrm{~L}^{-1}(\mathrm{KCl})$ ) and the oxocation $\mathrm{VO}^{3+}$ (titrant $\mathrm{KOH}, 0.1 \mathrm{~mol}$ $\mathrm{L}^{-1}$ ). (The ligand alone, and the ratios metal to ligand 1:1 and 1:2 have respectively 31,35 and 27 points).

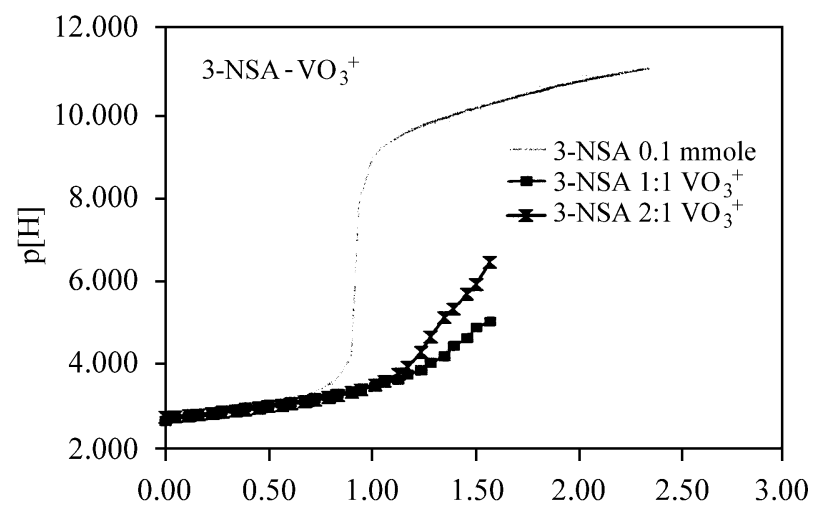

a / ( $\mathrm{n}$ mole $\mathrm{KOH} / \mathrm{n}$ mole ligand)

Figure 2. Potentiometric $\mathrm{p}[\mathrm{H}]$ profiles of $40 \mathrm{~mL}$ of $3-\mathrm{NSA}\left(0.01 \mathrm{~mol} \mathrm{~L}^{-1}\right.$; $\mu=0.100 \mathrm{~mol} \mathrm{~L}^{-1}(\mathrm{KCl})$ ) and the oxocation $\mathrm{VO}^{3+}$ (titrant $\mathrm{KOH}, 0.1 \mathrm{~mol}$ $\mathrm{L}^{-1}$ ). (The ligand alone, and the ratios metal to ligand $1: 1$ and 1:2 have respectively 43,24 and 28 points).

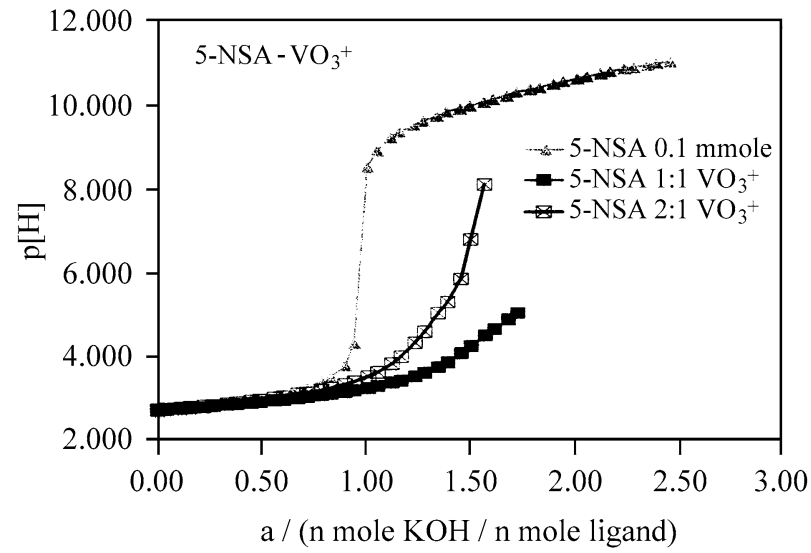

Figure 3. Potentiometric $\mathrm{p}[\mathrm{H}]$ profiles of $40 \mathrm{~mL}$ of 5-NSA $\left(0.01 \mathrm{~mol} \mathrm{~L}^{-1}\right.$; $\left.\mu=0.100 \mathrm{~mol} \mathrm{~L}^{-1}(\mathrm{KCl})\right)$ and the oxocation $\mathrm{VO}^{3+}$ (titrant $\mathrm{KOH}, 0.1 \mathrm{~mol}$ $\mathrm{L}^{-1}$ ). (The ligand alone, and the ratios metal to ligand $1: 1$ and $1: 2$ have respectively 45,32 and 29 points).

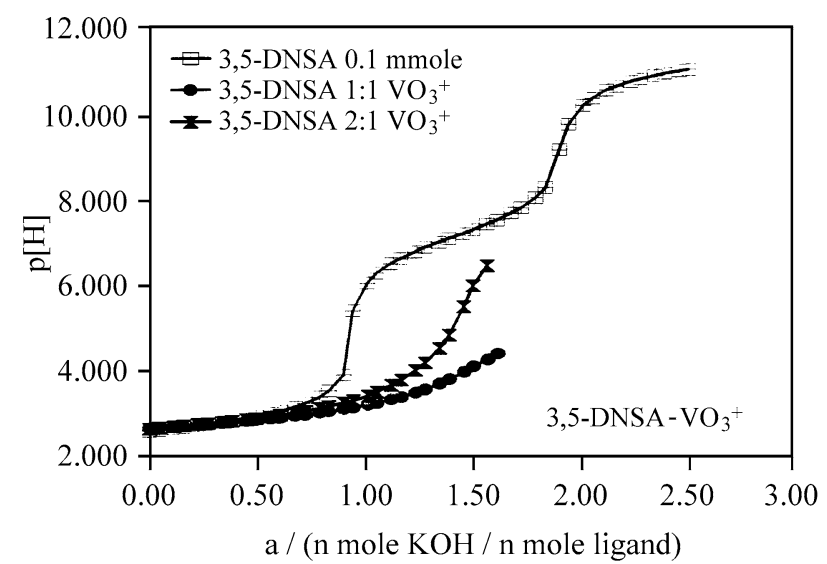

Figure 4. Potentiometric $\mathrm{p}[\mathrm{H}]$ profiles of 3,5-DNSA $\left(0.01 \mathrm{~mol} \mathrm{~L}^{-1} ; \mu=\right.$ $0.100 \mathrm{~mol} \mathrm{~L}^{-1}(\mathrm{KCl})$ ) and the oxocation $\mathrm{VO}^{3+}$ (titrant $\mathrm{KOH}, 0.1 \mathrm{~mol} \mathrm{~L}^{-1}$ ). (The ligand alone, and the ratios metal to ligand $1: 1$ and 1:2 have respectively 46,30 and 29 points).

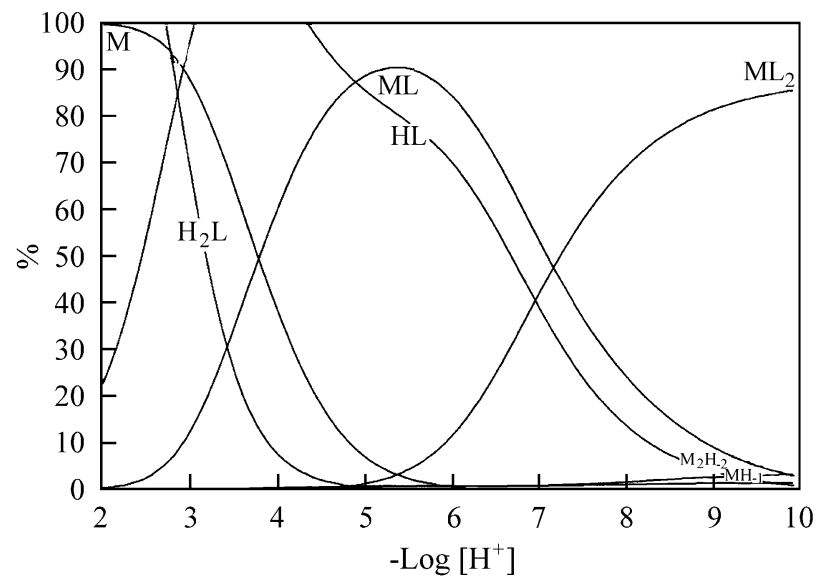

Figure 5. Species distribution diagram from $\mathrm{p}[\mathrm{H}] 2.0$ to 10.0 of a $2.5 \mathrm{x}$ $10^{-3} \mathrm{~mol} \mathrm{~L}^{-1}$ solution of SALA - $1.25 \times 10^{-3} \mathrm{~mol} \mathrm{~L}^{-1} \mathrm{VO}^{3+}$, with metal ion set at $100 \%$. $\mathrm{H}_{-\mathrm{x}}$ represents $(\mathrm{OH})_{\mathrm{x}}$.

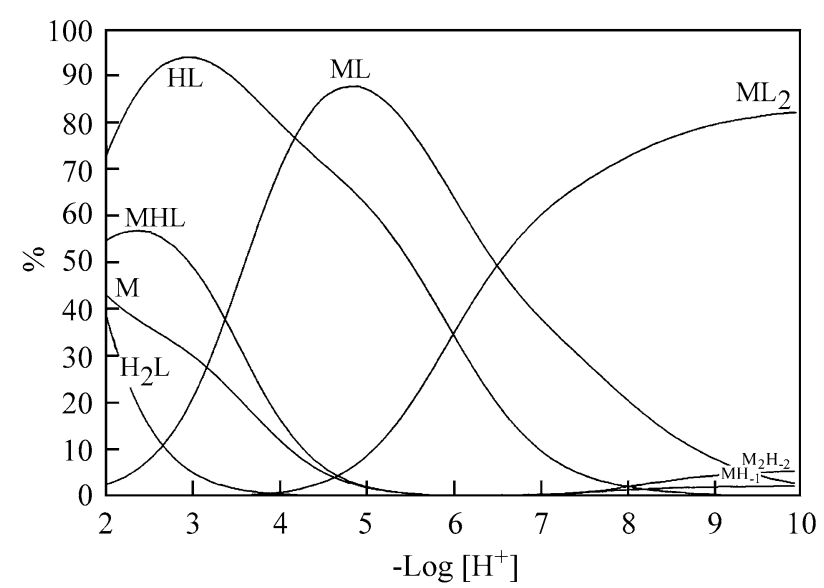

Figure 6. Species distribution diagram from $\mathrm{p}[\mathrm{H}] 2.0$ to 10.0 of a $2.5 \mathrm{x}$ $10^{-3} \mathrm{~mol} \mathrm{~L}^{-1}$ solution of 3-NSA - $1.25 \times 10^{-3} \mathrm{~mol} \mathrm{~L}^{-1} \mathrm{VO}^{3+}$, with metal ion set at $100 \%$. $\mathrm{H}_{-\mathrm{x}}$ represents $(\mathrm{OH})_{\mathrm{x}}$. 


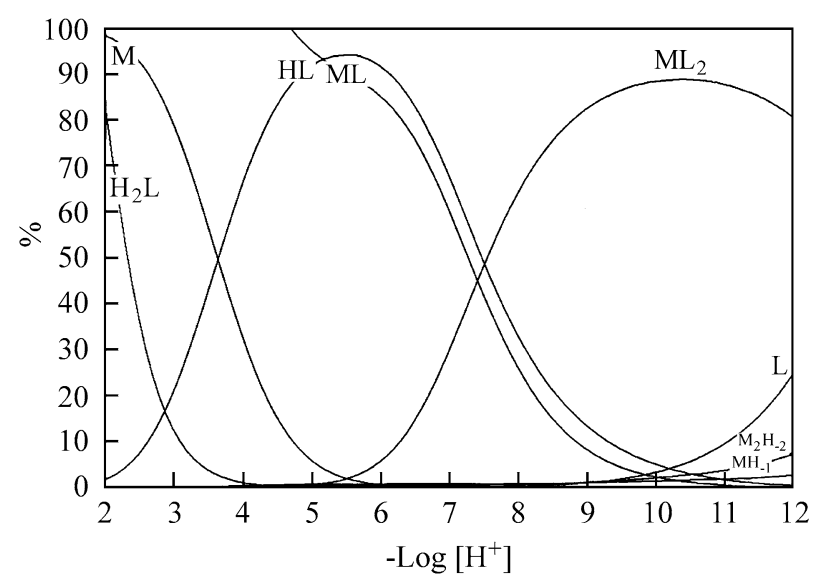

Figure 7. Species distribution diagram from $\mathrm{p}[\mathrm{H}] 2.0$ to 12.0 of a $2.5 \mathrm{x}$ $10^{-3} \mathrm{~mol} \mathrm{~L}^{-1}$ solution of 5-NSA - $1.25 \times 10^{-3} \mathrm{~mol} \mathrm{~L}^{-1} \mathrm{VO}^{3+}$, with metal ion set at $100 \%$. $\mathrm{H}_{\text {-x }}$ represents $(\mathrm{OH})_{\mathrm{x}}$.

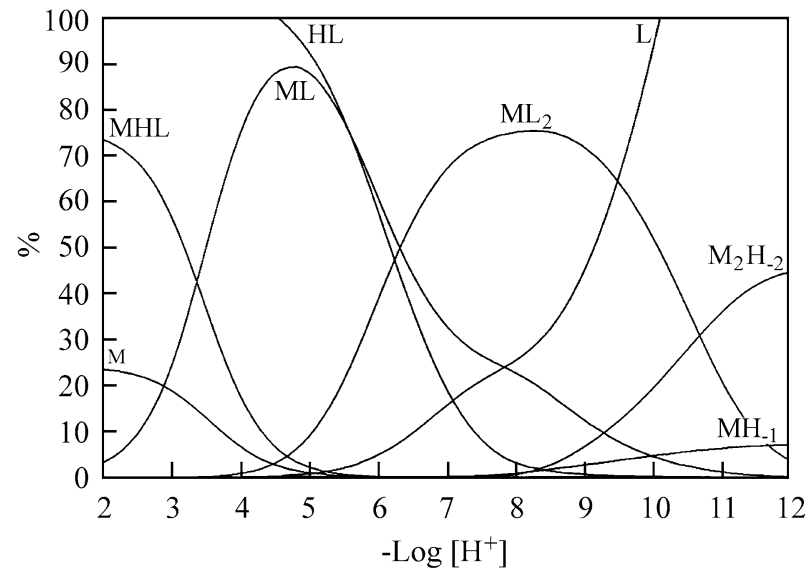

Figure 8. Species distribution diagram from $\mathrm{p}[\mathrm{H}] 2.0$ to 12.0 of a $2.5 \mathrm{x}$ $10^{-3} \mathrm{~mol} \mathrm{~L}^{-1}$ solution of $3,5-\mathrm{DNSA}-1.25 \times 10^{-3} \mathrm{~mol} \mathrm{~L}^{-1} \mathrm{VO}^{3+}$, with metal ion set at $100 \%$. $\mathrm{H}_{-\mathrm{x}}$ represents $(\mathrm{OH})_{\mathrm{x}}$.

significant quantities. The nitro- group in the ligandsresults in a shift of the $\mathrm{ML}_{2}$ species has brought the species to silightly more acid values in comparison to the SALA ligand, the exception being 5-NSA.

Recent works ${ }^{12,17}$ have shown that due to the more acidic behaviour of nitrosalicylic acids, a more pronounced difference in the distribution of species along with the variation of the $\mathrm{p}[\mathrm{H}]$ values compared to salicylic acid would be expected, especially the formation of at least one complexed species at lower $\mathrm{p}[\mathrm{H}]$ values for the nitrosalicylic acids than the salicylic acid. However, in the case of $\mathrm{VO}^{3+}$ this effect did not seem to be playing a major role, as this expected difference was not that remarkable.

The EPR parameters for the $\mathrm{VO}^{2+}$ complexes in aqueous solutions (Table 1) indicate the presence of oxygen donors in the equatorial plane of $\mathrm{C}_{4 \mathrm{v}}$ symmetry ${ }^{7-8}$. The complex of M:L ratio of 1:1 still bears two (or three in the case of MHL) molecules of water in the four equatorial coordination sites. The complex M:L ratio of 1:2 for its turn, is through 4 oxygen atoms of the two basic sites of two salicylic type molecules, the $-\mathrm{COO}^{-}$and phenolic $-\mathrm{O}^{-}$. Looking at the EPR isotropic parameters, $\mathrm{g}_{o}$ and $\mathrm{A}_{\mathrm{o}}$ and comparing to the logarithm of the overall stability constants ( $\beta$ ) taken as a measure of the ligand field force, it is seen that they follow a regular pattern according to a relation among those three parameters stated in the literature ${ }^{18}$. As $\log \beta$ values increase, the $g_{o}$ values increase while $A_{o}$ values show a tendency to decrease. This pattern may be accounted for the lower spin polarization of inner s electrons of vanadium atom as the ligand field becomes stronger.

Looking at the values of the stability constants in Table 2, the more basic ligand, SALA, presents the higher values for the stability constants of both ML and $\mathrm{ML}_{2}$ species, followed by 3-NSA, 5-NSA and 3,5-DNSA. The latter is the less basic of the four, due to having two nitro- substituents.

The detection of protonated species in the ratio $1: 1$ (MHL) (Table 2) for only 3-NSA and 3,5-DNSA and $\mathrm{VO}^{3+}$, the phenolic $-\mathrm{OH}$ group being protonated in the salicylic ring, leaving only the carboxyl group to complex, is probably because of steric effects imparted by the nitro substituent group in the C-3 position, present in both 3-NSA and 3,5-DNSA ligands. Also this protonated -OH may be hydrogen bridging the $-\mathrm{NO}_{2}$ group in the vicinal position, forming a six membered ring with some stability. As the $\mathrm{p}[\mathrm{H}]$ value increases, this stabilization effect disappears, leaving room for complexation through both $-\mathrm{COO}^{-}$and the phenolic $-^{-} \mathrm{O}^{-}$of one or two salicylic derivative molecules.

\section{Conclusion}

Although the molecules chosen as models are not sophisticated ones and do not to reproduce the inherently complex properties a geopolymer might have, as any model would $^{19}$, they have provided information concerning the aqueous equilibria for humic acid models for nitrosalicylic acids - oxovanadium complexes, as well as have shown the possibility of studying them by EPR spectroscopy in aqueous solutions, opening new perspectives in using them as slow-release fertilizers.

\section{Acknowlegdments}

We gratefully acknowledge UFPR sponsorship and CNPq fellowships.

\section{References}

1. Fraústo da Silva, J.J.R.; Williams, R.J.P. The Biological Chemistry of The Elements. The Inorganic Chemistry of Life. Clarendon Press, Oxford, 1997. p. 427.

2. Rehder, D. Angew. Chem. Int. Ed. Engl. 1991, 30, 148.

3. Rehder, D. Biometals 1992, 5, 3. 
4. Cortizo, A.M.; Etcheverry, S.B. Mol. Cell. Biochem. 1995, 145, 97.

5. Schulten, H.-R.; Schnitzer, M. Naturwissenschaften 1993, 80, 29.

6. Sposito, G. The Chemistry of Soils, Oxford University Press, N.Y., p 51, 1989.

7. Mangrich, A.S.; Vugman, N.V. Fuel 1990, 69, 925.

8. Mangrich, A.S.; Vugman, N.V. Sci. Tot. Environ. 1988, 75, 235.

9. Buglyó, P.; Culeddu, N.; Kiss, T.; Micera, G.; Sanna, D. J. Inorg. Biochem. 1995, 60, 45.

10. Kiss, T.; Buglyó, P.; Sanna, D.; Micera, G.; Decock, P.; Dewaele, D. Inorg. Chim. Acta 1995, 239, 145.

11. Micera, G.; Dessí, A. J. Inorg. Biochem. 1989, 35, 71.

12. Mercê, A.L.R.; Mangrich, A.S.; Szpoganicz, B.; Levy, N.M.; Felcman, J. J. Braz. Chem. Soc. 1996, 7, 239.
13. Martell, A.E.; Motekaitis, R.J. The Determination and Use of Stability Constants, VCH, New York, 1992.

14. Furman, N.H. Standard Methods of Chemical Analysis. V. 1. D. Van Nostrand Co. Inc., N.Y., p. 1211, 1962.

15. Mercê, A.L.R.; Szpoganicz, B.; Dutra, R.C.; Khan, M.A.; Do Thanh, X.; Bouet, G. J. Inorg. Biochem. 1998, $71,87$.

16. Baes Jr., C.F.; Mesmer, R.E. The Hydrolysis of Cations, John-Wiley \& Sons, N.Y., USA, p 200.

17. Mercê, A.L.R.; Mangrich, A.S.; Szpoganicz, B.; Levy, N.M.; Felcman, J. J. Braz. Chem. Soc. 1996, 7, 97.

18. Goodman, B.A.; Raynor, J.B. Advanc. Inorg. Chem. Radiochem. 1970, 13, 135.

19. Garret, T.M.; Miller, P.W.; Raymond, K.N. Inorg. Chem. 1989, 28, 128. 